\title{
CORRELATIONS BETWEEN SYMPTOMS AND DAS - ELISA VALUES IN TWO SOURCES OF RESISTANCE AGAINST TOMATO SPOTTED WILT VIRUS
}

\author{
Luciane V. Resende ${ }^{1 *}$; Wilson R. Maluf²; Antônia dos R. Figueira ${ }^{3}$; Juliano T.V. Resende ${ }^{2}$ \\ ${ }^{1}$ Programa de Pesquisa para Agricultura Irrigada, Empresa Pernambucana de Pesquisa Agropecuária, Recife, PE, Brasil. \\ ${ }^{2}$ Departamento de Agricultura, Universidade Federal de Lavras, Lavras, MG, Brasil. ${ }^{3}$ Departamento de Fitossanidade, \\ Universidade Federal de Lavras, Lavras, MG, Brasil
}

Submitted: February 18, 1999; Returned to authors for corrections: June 30, 1999; Approved: March 28, 2000

\begin{abstract}
The commercial tomato, Lycopersicon esculentum, cultivars Ângela Gigante I-5100 and Santa Clara (tospovirus susceptible), the Stevens cultivar, lines and experimental hybrids (tospovirus resistant), were used: a) to evaluate two sources of resistance to tospoviruses in tomato (one from L. esculentum/Rey de Los Tempranos, and another one from L. peruvianum/Stevens); and b) to verify statistically significant correlation between virus concentration determined through DAS-ELISA and symptomatology. In the Ângela Gigante I5100 and the Santa Clara cultivars, the correlation coefficient was highly significant and the symptom average level was high, showing that in susceptible cultivars the symptom evolution is related to the virus multiplication in the plant. As for the TOM 547 and TOM 556 lines (background of Ângela Gigante I-5100 and Santa Clara, respectively), there was no statistical correlation between the symptoms and the viral particle concentration. Plants with light virus symptoms showed high absorbance values. Consequently we may assume that the resistance with 'Rey de Los Tempranos' background may be of the tolerant kind because the high virus concentration found does not necessarily relate to a high level of symptoms. In the lines BPX320E 3902-01, BPX320E 3905 and BPX320F 7902 (both with Santa Clara background) only few plants showed symptoms, which can be explained by incomplete penetrance of Sw-5 gene. In the case of non-symptomatic plants, the diagnosis using DAS-ELISA revealed negative results. That outcome indicates that in some materials, where resistance is obtained from $L$. peruvianum, the virus multiplication in the tissues seemed not be present.
\end{abstract}

Key words: Tospovirus, breed lines, viruses infection

\section{INTRODUCTION}

The identification and screening of sources of resistance to tospoviruses have been made by the inoculation of healthy plants through mechanical procedures, field natural infection, or greenhouse thrips-mediated inoculation. Disease symptoms have been evaluated by scoring plants on scale from one (nonsymptoms plants), to five (dead plants) $(8,4,2,6)$, and/or through serological tests, such as ELISA $(5,7,3)$.

When compared, those evaluation criteria have led to different conclusions, as to the resistance or susceptibility of the tested materials. This has been the case with the evaluation of Tomato spotted wilt virus (TSWV)-resistance source in Lycopersicon esculentum cv. Rey de Los Tempranos Upreti and Hartmann (8), rating disease symptoms on a scale of one to five, considered 'Rey de Los Tempranos' to be resistant, with few plants showing severe disease symptoms. Maluf et al. (4), using a similar rating system, classified Rey de Los Tempranos as tolerant, because it presents plants not only with light symptoms of the disease but also with normal fruit development.

\footnotetext{
* Corresponding author. Mailing address: Rua Afonso Batista, 201/301, CEP 52021-020, Recife, PE, Brasil, E-mail:luciane@ipa.br; 1vilela@elogica.com.br
} 
On the other hand, Paterson et al.(5) and Kumar and Ullman (3), evaluating inoculated plants by ELISA considered 'Rey de Los Tempranos' to be tospovirus susceptible.

Therefore, different evaluation criteria have been responsible for different conclusions, in regard with the reaction of putative TSWV-resistance sources. Thus, resistant germ plasm could be unduly discarded as susceptible, depending on the evaluation methodology. Despite the contradiction in results, the literature clearly characterizes the existence of differences between the sources of resistance in L. esculentum/ Rey de Los Tempranos on one hand, and Stevens/L. peruvianum on the other hand, concerning the expression of resistance mechanisms. Contradictions could be due either to different genetic backgrounds of the tested accessions, or to different genes which control the resistance.

The objective of this work was to compare the levels of symptom expressions and tospovirus concentration in plants of similar genetic backgrounds (Santa Cruz group), but with TSWV resistance derived from different sources (Rey de Los Tempranos/L. esculentum and Stevens/L. peruvianum), and presumably with different genetics controls. This paper aims to examine the putative different mechanisms of resistance involved, and to define an appropriate strategy to obtain tospovirus resistant cultivars.

\section{MATERIALS AND METHODS}

The experiment used 12 different genotypes, including commercial cultivars, lines and hybrids already tested for tospovirus resistance (Table 1).

Table 1. Type of the genotypes and number of plants used to evaluate the symptoms and the virus concentration through DAS-ELISA.

\begin{tabular}{lcc}
\hline Genotype & Type & Plant' Number \\
\hline Angela & Cultivar & 10 \\
Santa Clara & Cultivar & 60 \\
Stevens & Cultivar & 10 \\
TOM547 & Line & 10 \\
TOM556 & Line & 70 \\
BPX 320E 3905 & Line & 10 \\
BPX 320F 7902 & Line & 74 \\
BPX 320F 3902-01 & Line & 14 \\
F $_{1}$ (TOM556 x BPX 320D 7902) & Hybrid & 24 \\
$\mathrm{~F}_{1}$ (TOM556 x BPX 320D 3902-01) & Hybrid & 24 \\
$\mathrm{~F}_{1}$ (TOM556 x Santa Clara) & Hybrid & 22 \\
$\mathrm{~F}_{1}$ (S. Clara x BPX 320D 3902-01) & Hybrid & 23 \\
\hline
\end{tabular}

The commercial Brazilian cultivars Ângela Gigante I-5100 and Santa Clara are known to be susceptible to tospoviruses. The breeding lines TOM 547 and TOM 556, with background Ângela Gigante I -5100 and Santa Clara respectively, present resistance to tospovirus obtained from $L$. esculentum/Rey de Los Tempranos (RT), confirmed by Maluf et al. (4) and Juliatti and Maluf (2), in natural field infection and by mechanical inoculation, respectively. The lines BPX 320E 3902-01, BPX320D3905 and BPX320E 7902 have Santa Clara genetic background and the resistance obtained from Stevens (St) cultivar, by mechanical inoculation and by natural field infection (Resende et al. (6)). The cv. Stevens, originated from South Africa, has its resistance derived from L. peruvianum (9). The tested hybrids have a similar Santa Clara background and represent different combinations of resistant-RT x resistant-St, resistant-RT x susceptible, or resistant-St x susceptible lines.

The tospovirus isolate was collected in Ijaci county, Minas Gerais, Brazil, and identified later by DAS-ELISA as TSWV. That isolate was maintained in mechanically inoculated tobacco plants cv.Turkish "NN", which showed symptoms like ringspots and systemic mosaic. The tomato plants were inoculated eight days after being transplanted. TSWV - infected tobacco leaves were smashed in a mortar, using the proportion of four grams of

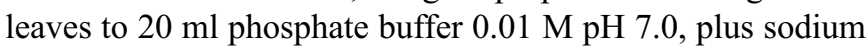
sulfite in the same concentration (1). The leaf extract was mechanically inoculated by rubbing the tomato leaflets with carborundum 300 mesh.

The experiment was carried out in a plastic greenhouse, with plants cultivated in $8 \mathrm{~L}$ - pots, with two plants per pot. Plants of each tested genotype, inoculated only with phosphate buffer, were used as controls.

The genotypes were rated for disease symptoms according to a scale from one to five $(4,8)$. Inoculated plants were also tested by DAS-ELISA, using a commercially available enzymelinked immunosorbent assay kit (Agdia Inc. Mishawaka Indiana). Evaluations were made 20 and 30 days after inoculation, in 30 and 45-day-old plants, respectively. Extracts from symptomless-ELISA-negative plants were inoculated in tobacco cv.Turkish "NN" plants, 30 days after each evaluation, in an attempt to recover the virus.

Disease symptoms were correlated ( $r$ ) to the absorbance values obtained by DAS-ELISA, within each genotype tested. The significance of the correlation was tested using Student $(t)$ statistic.

\section{RESULTS AND DISCUSSION}

Ângela Gigante I-5100 and Santa Clara cultivars, showed a significant correlation between the absorbance values and disease symptom scale (Tables 2, 3 and 4), showing that disease symptoms closely followed virus multiplication in the plant tissue. The mean ratings for those cultivars are close to 4 , and the absorbance values are high $(>1.5)$.

The lines TOM 547 and TOM 556, with Ângela Gigante I5100 and Santa Clara backgrounds, respectively, did not show a significant correlation, despite being almost isogenic to its susceptible counterparts (Table 2). We may not conclude that 
virus absence or presence in TOM-547/TOM-556 is necessarily followed by economic damage, because we did not verify a correlation between the symptoms and the virus concentration in the tissues. Therefore, in those lines symptoms, and consequently economic damage, are not necessarily associated with virus multiplication in tissues, as assumed by Paterson et al. (5). We verified that TOM 547 and TOM 556, despite the high virus title in the tissues, were more resistant to disease symptoms development than their susceptible counterparts. These results validate the use of the resistance source 'Rey de Los Tempranos' in breeding programs, as reported by Upreti Hartmann (8) and Maluf et al. (4). The occurrence of delay in symptom expression will contribute to decrease the economic loss. This resistance, or tolerance, seems to be more evident when natural infection by thrips is used $(4,3$,$) , but it can also be$ observed with mechanical inoculation $(2,6)$. In the present case, tolerance seems to occur.

The hybrid F (TOM-556 x Santa Clara) shares a Santa Clara background and it is heterozygous for the genes that control resistance in 'Rey de Los Tempranos'. It presents mean symptoms higher than those for TOM-556, especially in the 2nd evaluation, and associated with slightly higher correlations between symptom expression and DAS-ELISA readings. Those results can be explained by the incomplete dominance of the genes that control this kind of resistance (2).

The Stevens cultivar also showed a high correlation between disease symptom and absorbance values. The plants which were graded 1 (symptomless plants), presented a negative results in ELISA, while plants graded 2 and 4 (with light and heavy symptoms, respectively) showed a positive results. Stevens et al. (7) obtained similar results, in symptomless plants, in populations, which resulted from crosses with Stevens and showed negative results in ELISA. Paterson et al. (5) and Kumar and Ullman (3) had similar results when testing sources of resistance in L. peruvianum, and suggested that there was no virus multiplication in the tissues and, consequently, no symptoms. The presence of few plants with symptoms and high absorbance in DAS-ELISA in cv. Stevens can be due to an incomplete penetrance of the Sw-5 gene, which controls the resistance (7). The presence, in low frequency, of symptomatic plants in cv. Stevens reported by Stevens et al. (7), associated with high values of absorbance, explain the high correlation between symptomatology and the results in DAS-ELISA. However, in the majority of plants which remanded symptomless ( $98.96 \%)$, the presence of virus could not be detected by DASELISA.

Lines BPX 320E 3902-01, BPX 320E 3905 and BPX 320F 7902, which share the same 'Stevens'-derived resistance, showed a behavior similar to the one expected from the latter cultivar. We found high correlations between symptoms and DAS-ELISA absorbance, in all cases where the full range of symptoms (Tables 2 and 4). The same kind of results was found for the hybrids in which those lines were used as parents (Tables 3,4), reflecting the dominant gene action of Sw-5.

The association of symptomless plants with negative DASELISA results Tables 3 and 4) supports the hypothesis that Stevens cultivar- derived resistance is of the immune or hypersensitive type.

The results in this experiment clearly indicate that the resistance mechanisms involved must be taken into account when choosing a technique for disease resistance screening. The DASELISA as the decisive criterion to classify resistant plants as

Table 2. Correlations (r) between plant symptoms and TSWV tittle detected by serological test (DAS - ELISA) in mechanically inoculated tomato plants.

\begin{tabular}{|c|c|c|c|c|c|c|}
\hline \multirow{2}{*}{ Genotypes } & \multirow{2}{*}{ Background } & \multirow{2}{*}{ Source of Resistance } & \multicolumn{2}{|c|}{$1^{\text {St }}$ Evaluation } & \multicolumn{2}{|c|}{$2^{\text {nd }}$ Evaluation } \\
\hline & & & $\mathrm{r}$ & $\mathrm{t}$ & $\mathrm{r}$ & $\mathrm{t}$ \\
\hline Ângela G. I5100 & Ângela G. I5100 & - & 0.685 & $4.26^{* *}$ & - & - \\
\hline TOM 547 & Ângela G. I5100 & R. Los Tempranos & 0.457 & $1.71 \mathrm{~ns}$ & - & - \\
\hline Santa Clara & Santa Clara & - & 0.483 & $4.16^{* *}$ & 0.310 & $1.38 *$ \\
\hline TOM 556 & Santa Clara & R. Los Tempranos & 0.207 & $1.61 \mathrm{~ns}$ & 0.408 & $2.36 \mathrm{~ns}$ \\
\hline Stevens & Stevens & Stevens & 0.919 & $2.64 * *$ & - & - \\
\hline BPX320E 3902-01 & Santa Clara & Stevens & 0.435 & $4.35 * *$ & 0.125 & $0.28 \mathrm{~ns}$ \\
\hline BPX320E 3905 & Santa Clara & Stevens & 0.000 & - & - & - \\
\hline BPX320F 7902 & Santa Clara & Stevens & 0.805 & $0.68 * *$ & 0.816 & $8.71 * *$ \\
\hline $\mathrm{F}_{1}(\mathrm{TOM} 556 \times \mathrm{BPX} 320 \mathrm{D}$ 3902-01) & Santa Clara & R. Los Tempranos x Stevens & 0.823 & $6.79 * *$ & 0.547 & $1.84 * *$ \\
\hline $\mathrm{F}_{1}(\mathrm{TOM} 556 \times \mathrm{BPX} 320 \mathrm{D} 7902)$ & Santa Clara & R. Los Tempranos x Stevens & 0.858 & $7.85 * *$ & 0.779 & $4.79 * *$ \\
\hline $\mathrm{F}_{1}(\mathrm{TOM} 556$ x Santa Clara) & Santa Clara & R. Los Tempranos & 0.438 & $2.187 * *$ & 0.430 & $1.26^{* *}$ \\
\hline $\mathrm{F}_{1}($ Santa Clara x BPX320D3902-01) & Santa Clara & Stevens & 0.657 & $3.992 * *$ & 0.571 & $1.97 * *$ \\
\hline
\end{tabular}

\footnotetext{
**, * Significant $1 \%$ and $5 \%$ respectively by statistical Student-t test.
} 
the results in this experiment clearly indicate that the resistance mechanisms involved must be taken into account when choosing a technique for disease resistance screening. The DAS-ELISA as the decisive criterion to classify resistant plants as suggested by Paterson et al. (5) can be inappropriate to evaluated tolerance types of resistance such as the ones displayed by Rey de Los Tempranos. Methods of inoculation may also play a role when assessing resistance because lines considered to be resistant, under natural (field) vector-infection, can behave as susceptible under mechanical inoculation, where inoculum pressure is presumably bigger. In fact Kumar and Ullman (3) reported that some materials resistant to the transmission by thrips (among them Rey de Los Tempranos), are not necessarily resistant to mechanical inoculation. This can be only a result of a smaller initial inocullum, in thrips transmission, plus a virus multiplication not strongly attached to the presence of symptoms. The result of such process is a delay in the disease manifestation, and therefore a field resistance.
In fact, both natural infection by thrips (4), and by mechanical inoculation (2), have been successfully employed in selecting resistant lines to tospovirus from Rey de Los Tempranos, when progeny of a reasonable size was used for evaluation.

This paper points to the possibility of obtaining a genetic material with two sources of resistance: 'Stevens' and 'Rey de Los Tempranos'. The problem to achieve the pirimmidization of the gene(s) that control these resistances was the difficulty to differentiate on the basis of symptomatology, plants with only one source of resistance and those with both sources. It became clear that the resistance from 'Stevens' does not allow virus multiplication in tissues, except when penetrance is less than $100 \%$. In materials with Rey de Los Tempranos there is a virus multiplication, but as symptoms do not appear to follow the virus multiplication in the same speed it results on a resistance of the tolerance type.

A possible breeding strategy would include the use of two lines in similar genetic background, but differing in their sources

Table 3. Means and ranges of TSWV symptoms ratings and of DAS-ELISA absorbance values in tomato plants evaluated 20 days after mechanical inoculation.

\begin{tabular}{lcccccc}
\hline & \multicolumn{2}{c}{$\begin{array}{c}\text { Symptoms } \\
\text { (ratings) }\end{array}$} & & \multicolumn{2}{c}{$\begin{array}{c}\text { DAS-Elisa } \\
\text { (absorbance values) }\end{array}$} \\
\cline { 2 - 3 } \cline { 5 - 6 } Genotypes & Means & Range & & Means & Range \\
\hline Angela & 4.00 & $1-5$ & & 1.562 & $0.078-2.810$ \\
TOM 547 & 2.70 & $1-4$ & & 1.230 & $0.271-2.141$ \\
Santa Clara & 3.97 & $1-5$ & & 1.8656 & $0.086-3.055$ \\
TOM 556 & 2.68 & $1-5$ & & & 1.6307 & $0.061-3.034$ \\
Stevens & 1.40 & $1-4$ & & & 0.444 & $0.076-1.970$ \\
BPX320E 3902-01 & 2.43 & $1-4$ & & & 0.641 & $0.460-1.165$ \\
BPX320E 3905 & 1.00 & 1 & & & 0.112 & $0.090-0.136$ \\
BPX320E 7902 & 1.36 & $1-5$ & & 0.346 & $0.079-0.117$ \\
F $_{1}$ (TOM556 x BPX320D 3902-01) & 2.46 & $1-5$ & & & 1.017 & $0.073-2.256$ \\
$\mathrm{~F}_{1}$ (TOM556 x BPX320D 7902) & 1.96 & $1-5$ & & 0.460 & $0.078-1.678$ \\
$\mathrm{~F}_{1}$ (TOM556 x Santa Clara) & 3.32 & $1-5$ & & 1.808 & $0.125-2.746$ \\
$\mathrm{~F}_{1}$ (Santa Clara x BPX3203902-01) & 3.23 & $1-5$ & & 1.0155 & $0.095-2.401$ \\
\hline
\end{tabular}

Table 4. Means and ranges of TSWV symptoms ratings and of DAS - ELISA absorbance in tomato plants evaluated 45 days after mechanical inoculation.

\begin{tabular}{lcccccc}
\hline & \multicolumn{2}{c}{$\begin{array}{c}\text { Symptoms } \\
\text { (ratings) }\end{array}$} & & \multicolumn{2}{c}{$\begin{array}{c}\text { DAS-Elisa } \\
\text { (absorbance values) }\end{array}$} \\
\cline { 2 - 3 } \cline { 5 - 6 } Genotypes & Means & Range & & & Means & Range \\
\hline Santa Clara & 4.25 & $3-5$ & & & 2.703 & $1.265-5.716$ \\
TOM 556 & 3.23 & $1-5$ & & & 1.469 & $0.067-2.978$ \\
BPX320E 3902-01 & 1.28 & $1-3$ & & & 0.292 & $0.062-0.515$ \\
BPX320E 7902 & 1.82 & $1-4$ & & & 1.244 & $0.065-1.894$ \\
F $_{1}$ (TOM556 x BPX320 D 3902-01) & 2.40 & $1-5$ & & & 1.218 & $0.059-0.075$ \\
F $_{1}$ (TOM556 x BPX320 D 7902) & 2.70 & $1-5$ & & & 0.369 & $0.049-0.815$ \\
F $_{1}$ (TOM556 x Santa Clara) & 4.44 & $2-5$ & & & 0.504 & $0.068-0.996$ \\
F $_{1}$ (Santa Clara x BPX320D3902-01) & 3.50 & $2-5$ & & 0.560 & $0.082-0.841$ \\
\hline
\end{tabular}


of resistance. TOM-556 (RT-source), and BPX320F 7902 (Stsource) could be used in a backcross program where the former would be used as the recurrent parent and the latter the nonrecurrent one. Selection in all segregations generations would be towards symptomless plants that would result negative in DAS-ELISA test, thus allowing for the selection of the $\mathrm{Sw}-5$ gene. Resistant gene(s) from 'Rey de los Tempranos' would be recovered by a reasonable number $(>6)$ of backcrosses. The ultimate end product would be a true breeding line in Santa Clara background, with both sources of resistance. An alternative strategy can also be considered, i.e., the commercial deployment of $F_{2}$ generation. Due to the low genetic divergence between TOM-556 and BPX320F 7902 (both in Santa Clara background), $\mathrm{F}_{2}$ is expected to be horticulturally uniform, but as far as TSWV resistance is concerned, it will be composed by different genotypes (nine, if monogenic inheritance is assumed in both cases). This genotypic diversity, which would include only a small proportion of fully susceptible plants, could contribute to greater stability of the sources of resistance through time.

\section{RESUMO}

\section{Correlações entre sintomas de vira-cabeça e o teste serológico ELISA (DAS) em duas diferentes fontes de resistência a tospoviroses em tomateiro}

As cultivares comerciais Ângela Gigante I-5100 e Santa Clara (suscetíveis a tospovírus), a cultivar Stevens, e híbridos experimentais $\mathrm{F}_{1}$ (resistentes a tospoviroses), foram utilizadas para: a) avaliar duas fontes de resistência a tospovírus em tomate, uma derivada de Lycopersicon esculentum / 'Rey de Los Tempranos', e a outra derivada de L. peruvianum/'Stevens'; b) verificar se existe uma correlação entre a concentração de partículas, detectadas por ELISA (DAS) e sintomatologia. Nas cultivares Ângela Gigante I-5100 e Santa Clara esta correlação foi altamente significativa, e o nível médio de sintomas foi alto indicando que em cultivares suscetíveis a evolução de sintomas acompanha a multiplicação do vírus na planta. Já para as linhagens TOM 547, e TOM 556, (background de Ângela Gigante I-5100 e Santa Clara respectivamente), não houve correlação entre a presença de sintomas e a concentração de partículas: plantas com sintomas leves do vírus, apresentaram altos valores de absorbância. Nas linhagens BPX320E 390201, BPX320E 3905 e BPX320E 7902 (background Santa Clara), poucas plantas apresentaram sintomas, o que é explicado pela penetrância incompleta do gene Sw-5. Para as plantas assintomáticas os diagnósticos empregando DAS-ELISA apresentaram resultados negativos, mostrando que em materiais cuja fonte de resistência é obtida de $L$. peruvianum, parece não haver a multiplicação do vírus nos tecidos, ou se houver a quantidade de partícula seria mínima, insuficiente para ser detectada por esta técnica.

Palavras-chave: Tospovírus, resistência genética, viroses.

\section{REFERENCES}

1. Duval, C..M.; Cupertino, F.P.; Luiz, A.B.P. ; Giordano, L. de B. Metodologia de inoculação de tospovírus visando avaliação de germoplasma de tomate. Fitop. Bras. 18(4):516-521, 1993.

2. Juliatti, F.C.; Maluf, W.R. Controle genético da resistência do tomateiro a um isolado de tospovírus (TSWV) - análise de plantas individuais. Fitop. Bras.ileira 20(1): 39-47, 1995.

3. Kumar, N.K.; Ullman, D.E. Evaluation of Lycopersicon germ plasm for tomato spotted wilt tospovirus resistance by mechanical and thrips transmission. Plant Disease 77(9): 938-941, 1993.

4. Maluf, W.R.; Toma-Braghini, M.; Corte, R.D. Progress in breeding tomatoes for resistance to tomato spotted wilt. Rev. Bras. Gen. 14:509$525,1991$.

5. Paterson, R.G.; Scott, S.J; Gergerich, R.C. Resistance in two Lycopersicon species to an Arkansas isolated of tomato spotted wilt virus. Euphytica 43:173-178, 1989.

6. Resende, L.V.; Maluf, W.R.; Resende, J.T.V. Caracterização de linhagens de tomateiro Lycopersicon esculentum Mill., do tipo Santa Clara quanto à resistência ao vírus do vira-cabeça. Hort. Bras. 13(1):110, 1995 (Abstr. 262).

7. Stevens, M.R., Scott, S.J.; Gergerich, R.C. Inheritance of a gene for resistance to tomato spotted wilt virus (TSWV) from Lycopersicon peruvianum Mill. Euphytica 59(1):9-17, 1991.

8. Upreti, G.; Hartmann, R.W. Inheritance of resistance to spotted wilt virus in tomato. J.Inst. Agricult. Anim. Sci. 4:19-25, 1984.

9. Van Zijl, J.J.B.; Bosh, S.E.; Coetzee, C.P.J. Breeding tomatoes for processing in South África. Acta Horticult. 194:69-75,1986. 